\title{
A Narrative Review on Anti-Tumor Necrosis Factor a Therapies in Inflammatory Bowel Disease During Pregnancy: Immunoglobulin Placental Translocation and its Impact
}

\section{Revisão Narrativa sobre a Terapêutica com Agentes Anti-Tumor Necrosis Factor a na Doença Inflamatória Intestinal Durante a Gravidez: Translocação Placentária de Imunoglobulinas e seu Impacto}

\author{
Joana ROSEIRA $\square^{1}$, Jaime RAMOS ${ }^{2}$ \\ Acta Med Port 2019 Apr;32(4):305-312 - https://doi.org/10.20344/amp.11482
}

\begin{abstract}
Introduction: Inflammatory bowel disease activity is associated with adverse pregnancy outcomes. Anti-tumor necrosis factor $\alpha$ therapy is often required to treat flares and to maintain disease remission. However, there are concerns regarding treatment with these agents during pregnancy, as they actively cross the placental barrier.

Material and Methods: Studies regarding anti-tumor necrosis factor $\alpha$ therapy during pregnancy were identified from PubMed from 1958 to January 2018. The reference lists of the selected studies were reviewed to identify complementary publications.

Results and Discussion: Anti-tumor necrosis factor $\alpha$ agents are efficient treatments for moderate-to-severe inflammatory bowel disease and may ensure remission during pregnancy. Although these drugs cross the placenta, they are considered safe for both the mother and the fetus. Furthermore, up-to-date guidelines support therapy continuation during pregnancy aiming for disease control. The same guidelines also consider stopping treatment during the third trimester to limit maternal-fetal drug transfer. However, data shows that this strategy does not completely prevent fetus exposure. In addition, stopping treatment incurs in risk of disease flare and threatens subsequent therapy response. Fetus drug exposure has not showed an association with adverse childhood development. However, as infant drug levels could be detected up to seven months after birth, postponement of live virus vaccination is recommended. Conclusion: There should be no disagreement among the medical community as to the need to maintain therapy aiming for disease remission during gestation in inflammatory bowel disease. Anti-tumor necrosis factor $\alpha$ agents are safe for both the mother and the fetus.
\end{abstract}

Keywords: Adalimumab; Infliximab; Inflammatory Bowel Disease; Pregnancy; Tumor Necrosis Factor-alpha

\section{RESUMO}

Introdução: O melhor preditor de complicações durante a gravidez, na doença inflamatória intestinal, é a atividade da doença. A terapêutica com agentes anti-tumor necrosis factor $\alpha$ atravessa a barreira placentária o que levanta questões relativamente à sua segurança durante a gravidez.

Material e Métodos: Revisão bibliográfica suportada a partir de artigos indexados na PubMed (1958 a 01/2018) sobre a terapêutica anti-tumor necrosis factor $\alpha$ durante a gravidez na doença inflamatória intestinal.

Resultados e Discussão: Os agentes anti-tumor necrosis factor $\alpha$ são eficazes na doença inflamatória intestinal e podem garantir a remissão clínica durante a gravidez. Estes fármacos atravessam a barreira placentária, mas são seguros para a mãe e feto. Neste sentido, as orientações atuais defendem a manutenção terapêutica durante a gravidez para assegurar a remissão clínica. Paralelamente, as mesmas orientações consideram a suspensão terapêutica durante o terceiro trimestre para limitar a exposição fetal ao fármaco. No entanto, esta estratégia não só não previne totalmente a exposição fetal, como aumenta o risco de agudização da doença e da perda de resposta à terapêutica após o seu reinício. Esta exposição fetal não está associada a alterações do desenvolvimento in utero ou neonatal. Ainda assim, uma vez que é possível dosear fármaco no recém-nascido até aos sete meses de vida, recomenda-se adiar a administração de vacinas vivas em recém-nascidos expostos.

Conclusão: Não deve haver discordância na comunidade médica quanto à necessidade de garantir a remissão da doença inflamatória intestinal durante a gestação. Os agentes anti-tumor necrosis factor $\alpha$ devem ser vistos como opções terapêuticas seguras para mãe e feto durante a gravidez.

Palavras-chave: Adalimumab; Doença Inflamatória Intestinal; Fator de Necrose Tumoral alfa; Gravidez; Infliximab

\section{INTRODUCTION}

Biological therapies, namely anti-tumor necrosis factoralpha (anti-TNFa) agents, have become part of the effective treatment armamentarium for moderate-to-severe and difficult-to-treat inflammatory bowel disease (IBD). Fifty

percent of patients with IBD are women, many of whom are diagnosed during adolescence and early adulthood, ${ }^{1}$ making pregnancy an expected scenario at some point. For pregnant women, there is a recognized increased risk of

\footnotetext{
1. Serviço de Gastrenterologia. Hospital de Portimão. Centro Hospitalar Universitário do Algarve. Portimão. Portugal.

2. Serviço de Gastrenterologia. Hospital de Santo António dos Capuchos. Centro Hospitalar de Lisboa Central. Lisboa. Portugal.

$\bowtie$ Autor correspondente: Joana Selas Roseira. jsr_roseira@hotmail.com

Recebido: 28 de outubro de 2018 - Aceite: 18 de fevereiro de 2019 | Copyright @ Ordem dos Médicos 2019
} 
adverse pregnancy outcomes in the setup of active IBD. ${ }^{2-6}$ Therefore, current guidelines recommend that maintenance of disease remission is the most important factor for a successful pregnancy. ${ }^{7,8}$

Anti-TNFa drugs, such as infliximab and adalimumab, are immunoglobulin ( $\mathrm{lg}) \mathrm{G}$ antibodies, and can therefore actively cross from the maternal to the fetal blood compartment during pregnancy. ${ }^{9,10}$ Indeed, infliximab and adalimumab concentrations may be up to fourfold higher in infant circulation compared to maternal peripheral blood 9-14 and can still be measurable up to 7 months after birth. ${ }^{15}$

Despite maternal-fetal drug transfer, anti-TNFa treatment during gestation has not been shown to result in adverse pregnancy outcomes. ${ }^{7,8}$ Moreover, studies suggest that TNFa blockade does not appear to affect the development of the fetus either. ${ }^{16}$ However, the long-term effect on the emerging immune system remains unknown. The theoretical influence of anti-TNFa treatment on the fetus is a major concern for parents and clinicians.

It is the clinician's role to rationally balance this dual concern: IBD relapsing risk threatening pregnancy outcome and requiring maintenance therapy versus infant's theoretical immune system disruption risk, calling for therapy discontinuation.

Basic epidemiology, interventional trials, and real-world evidence on pregnancy outcomes among patients with IBD who have been exposed to anti-TNFa agents are lacking, making quantitative data scarce. Therefore, we conducted a narrative review, aiming to assess the best evidence on anti-TNF $\alpha$ agent's safety during pregnancy in patients with IBD.

\section{MATERIAL AND METHODS}

A search of literature was conducted to identify papers regarding anti-TNFa therapy during pregnancy in patients with IBD. The authors identified sources (abstracts and full text articles) from the PubMed database from 1958 to January 2018. Full texts published during 2018, referring to abstracts presented prior to January 2018 were also identified and analyzed. The search was narrowed to articles written in English, Portuguese, and French. MeSH terms were used in the search including: 'inflammatory bowel diseases'; 'colitis, ulcerative'; 'crohn disease'; 'pregnancy'; 'pregnancy outcome'; 'adalimumab'; 'infliximab'; 'tumor necrosis factor-alpha'; 'immunoglobulins'; 'placenta'; 'maternal-fetal exchange'. In addition, the reference lists of the identified studies were manually reviewed to identify complementary publications.
Approximately 160 articles were screened in the first round. Studies were included in this review if they met the following criteria: (1) meta-analysis revisions, editorials or expert reviews; (2) observational design (prospective, retrospective, case control and case series); (3) interventional design. Studies that did not report outcomes for an IBD-only and female-only population were excluded. Errata and commentary were also excluded. Insufficient data for extraction was recorded in 6 studies. Data extraction was carried out independently by two investigators (Roseira J, Ramos J) with discrepancies resolved by the senior author (Ramos $\mathrm{J}$ ).

The results and discussion section in this narrative review were organized in two main subtopics to obtain a more pleaded narration: (1) a physiology segment aiming to explore placental immunoglobulin translocation, and maternal-fetal exchange according to gestational week; (2) a clinical impact segment aiming to analyze the exposure of mothers, fetuses, and newborns to anti-TNFa agents.

\section{RESULTS AND DISCUSSION}

\section{1) Physiology}

Anti-TNFa agents during pregnancy in IBD explaining immunoglobulin maternal-fetal transfer

Crohn's disease (CD) and ulcerative colitis (UC), the main forms of IBD, are chronic and disabling diseases of the digestive tract. ${ }^{17}$ The introduction of biological therapies, in particular anti-TNFa agents, has dramatically changed the natural history of the disease. TNF $\alpha$ agents are primarily used to treat moderate-to-severe IBD in patients with inadequate response to standard medications. ${ }^{18}$ By inhibiting TNFa, these agents can restrict the inflammatory pathway by inhibiting cellular proliferation, migration, adhesion, and cytokine response. ${ }^{19}$

Currently, four anti-TNFa agents are approved by the United States Food and Drug Administration (USFDA) for the treatment of IBD, namely golimumab, certolizumab pegol, infliximab, and adalimumab (Table 1).

Available information concerning golimumab and certolizumab use during pregnancy is scarce and these agents will only be briefly reviewed here. Golimumab is a fully human IgG1-kappa monoclonal antibody approved in the United States and in European Union (EU) for moderate-to-severe UC. ${ }^{20}$ The potential negative effect of golimumab during pregnancy has not been studied in humans yet. However, animal studies (pregnant cynomolgus monkeys) showed no evidence of harm to the fetus. ${ }^{21}$ Certolizumab pegol is a recombinant antigen-binding fragment (fab') antibody against TNFa, which is conjugated with polyethylene glycol.

Table 1 - FDA-approved anti-TNFa agents for IBD

\begin{tabular}{lcccc}
\hline Name & Structure & Dosage form & Half-life & Approval \\
\hline Infliximab $\left(\right.$ Remicade $\left.^{\circledR}\right)$ & $\operatorname{lgG} 1$ & intravenous & 9.5 days & 1998 \\
Adalimumab $\left(\right.$ Humira $\left.^{\circledR}\right)$ & $\operatorname{lgG1}$ & subcutaneous & $10-20$ days & 2005 \\
Golimumab $\left(\right.$ Simponi $\left.{ }^{\circledR}\right)$ & $\operatorname{lgG} 1$ & subcutaneous & $7-20$ days & 2009 \\
Certolizumab pegol $\left(\right.$ Cimzia $\left.^{\circledR}\right)$ & Fab $^{\prime *}$ & subcutaneous & 14 days & 2008 \\
\hline
\end{tabular}


The drug is approved in the United States and in Switzerland for the treatment of $C D$ in adults but is not approved for IBD in the EU. ${ }^{22}$ Clinical experience with certolizumab pegol during pregnancy is sparse and there is little available information concerning fetal serum levels. Placental transport of fab" fragments has been demonstrated in animal studies (pregnant rats). ${ }^{23}$ However, a recent pharmacokinetic study looking at infants born to mothers exposed to certolizumab pegol (last dose at 35 days or less prior to delivery), found that $93 \%$ had no quantifiable drug levels at birth, and one newborn had an insignificant level of $0.042 \mu \mathrm{g} / \mathrm{mL} .{ }^{24}$ As such, certolizumab data during pregnancy needs further clarification. Infliximab and adalimumab were the first antiTNF $\alpha$ agents to be approved for IBD and they are the best studied agents so far. Both drugs are widely used for UC and CD in adult patients who have not responded to a full course of corticosteroids or immunosuppressant therapy. ${ }^{25,26}$ Infliximab is an engineered chimeric IgG1 monoclonal antibody, and adalimumab is a fully human IgG1 monoclonal antibody. These drugs both represent a clear advance in the treatment of IBD, offering the chance for clinical remission and mucosal healing in severe disease. ${ }^{27}$ However, once inflammation is controlled, the question of when to consider stopping anti-TNFa treatment frequently occurs. Reasons for stopping treatment most often include patients' concerns about adverse events, costs, or particular situations such as pregnancy. ${ }^{28}$

However, anti-TNFa treatment is indicated for moderate-to-severe disease to prevent disease flares. Continued prevention of flares is also crucial during pregnancy.

Several studies have revealed that women with active IBD at conception and during pregnancy have a higher risk of miscarriage, preterm delivery, and fetal growth restriction compared with women in disease remission. ${ }^{29-36}$ Anti-TNFa agents, such as infliximab and adalimumab are efficient for moderate-to-severe IBD and may ensure remission during pregnancy.

\section{Maternal-fetal interface development}

For decades it was presumed that the human placenta served as a barrier, protecting the fetus from xenobiotics that mothers could be exposed to. ${ }^{37}$ But as appropriate placental perfusion studies and placental villi cultures developed, it has become apparent that the placenta allows maternal-fetal drug transfer. ${ }^{38}$

The human placental barrier consists of a layer of multinucleated cells, known as syncytiotrophoblast. The syncytiotrophoblast layer is already formed 4 to 5 days after conception, when the blastocyst is implanted. Within the syncytiotrophoblast layer, lacunae emerge from the decidua where mother arterial and venous blood circulates. These lacunae, or blank spaces, are filled with maternal blood from the endometrial vessels. Among the lacunae, fetal chorionic tissue perfused by fetal vessels, develops. Together with the maternal blood lacunae, the fetal chorionic tissue forms a tree-like structure called villi, where the maternal-fetal interface is formed. ${ }^{39}$

\section{Placental xenobiotic transfer}

Most drugs cross the placenta by simple diffusion. However, other mechanisms of placental transfer may be involved, such as plasma membrane carriers, biotransformation enzymes, and export pumps. Factors that affect the drug transport include molecular weight, degree of ionization, lipid solubility, protein binding capacity, and fetal and placental blood flow. Nonionized, nonprotein-binding, lipid soluble drugs, with molecular weight below $600 \mathrm{Da}$, freely cross the placental barrier. On the other hand, high molecular weight drugs, such as insulin, are not transported in significant amounts. There are a few exceptions though, such as IgG, which can cross the placental barrier despite a large molecular mass of approximately $160 \mathrm{kDa}^{40}$

\section{Placental immunoglobulin transport}

Fetal immunity is acquired during pregnancy by transfer of IgG antibodies from the maternal to the fetal circulation. ${ }^{41}$ Of the five major classes of antibodies, only lgG is transferred across the placenta. Analysis of cord sera has shown that all $\lg$ subclasses are transmitted to the fetus but a preferential transport of IgG1 was found..$^{41}$

Data shows that maternal IgG concentrations increase in fetal blood from early in the second trimester through term, with most antibodies being acquired during the third trimester. ${ }^{42}$ As early as 1967 , Hobbs et $a l,{ }^{43}$ found an exponential relationship between total $\lg G$ and gestational age in preterm infants. Subsequent studies tried to address maternal-fetal lgG transfer per gestational trimester. Van den Berg et $a{ }^{44}$ demonstrated that in the first trimester, very little lgG is transported to the fetus. In the second trimester, the fetal IgG rises from approximately $10 \%$ of the maternal concentration at weeks $17-22$ of gestation to $50 \%$ at gestational weeks $28-32 .{ }^{45}$ In the third trimester, between gestational weeks 29 - 41, fetal lgG concentration is two times higher than between gestational weeks $17-28 .{ }^{42}$ By gestational weeks 37 - 40, infant cord blood concentration of maternal IgG often exceeds that of maternal serum ( $130 \%$ of maternal concentration) by the delivery time point in full-term healthy pregnancies. ${ }^{43,45,46}$ Similarly, other authors have demonstrated that the greatest rate of antibody transfer to the fetus is after gestational week $34 .{ }^{47}$ There are no reports showing that IgG is transferred back to the mother's circulation once it has reached the fetus. ${ }^{48}$

To be transferred from the maternal to the fetal blood compartment, IgG must overcome several anatomical barriers. Maternal lgG must cross the syncytiotrophoblast and cytotrophoblast cell layers and be transferred across the villous stroma to ultimately reach the lumen of the fetal endothelial vessels (Fig. 1). So far, the mechanism of IgG transplacental transfer across the distinct placental anatomical barriers is not completely elucidated. Early studies have demonstrated that the neonatal Fc receptor (FcRn) expressed on syncytiotrophoblast cells is a key contributor to IgG transplacental transfer. ${ }^{49} \mathrm{FcRn}$ at the surface of the syncytiotrophoblast binds the Fc portion of $\lg G$ at acidic $\mathrm{pH}$ environment. ${ }^{50}$ It is believed that maternal $\lg \mathrm{G}$ in the 


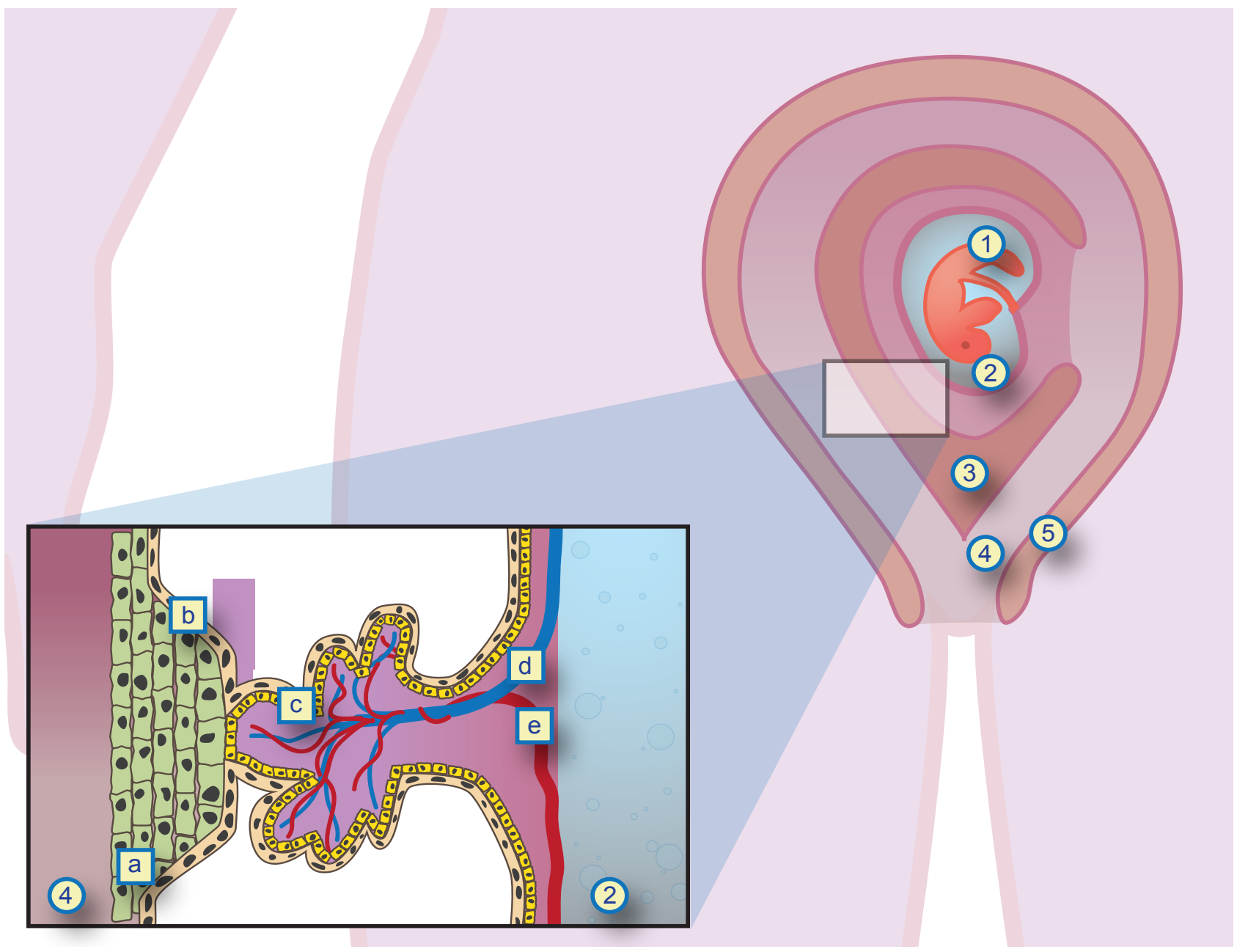

Figure 1 - Maternal-fetal interface

1: embryo; 2: amniotic cavity; 3: uterine cavity; 4: endometrium; 5: myometrium; a: cytotrophoblast; b: syncytiotrophoblast; c: villous trees; d: fetal vein; e: fetal artery.

Original sketch by Roseira J, adapted from Huppertz, et al description, remade in vector format by Acta Med Port graphic department.

intervillous space undergoes fluid-phase endocytosis into acidic endosomes that protect the immunoglobulin from proteolysis. Thereafter, the endosome is transported to the basal plasma membrane, where intact IgG is released into the fetal circulation, inside the villous tree. ${ }^{51}$

Placental transfer of anti-TNFa IgG such as infliximab and adalimumab follow the same pathway and timing, as FcRn is not able to discriminate beneficial from potentially harmful $\lg { }^{5} .2$

\section{2) Clinical Impact}

Exposure to infliximab and adalimumab - demystifying the risk for the mother, the fetus, and the newborn

Only a residual amount of IgG1 antibodies, including infliximab and adalimumab, cross the placental barrier during the first trimester. Therefore, infliximab and adalimumab do not have a teratogenic effect. ${ }^{7,45}$ However, as already stated, transfer of these agents across the placental barrier becomes significant in the second and third trimester, $9,10,42,45,47$ which still raises concerns among parents, obstetricians and the pediatric community.

Although anti-TNFa agents cross the placental barrier, there must be caution when limiting these efficient therapeutic options based on anxieties that are not evidencebased. For example: if patients flare during pregnancy because maintenance therapy with anti-TNFa was discontinued, they will have to undergo treatment with corticosteroids to control active disease. Corticosteroids are generally believed to be safe during pregnancy. But this may be true only at doses up to $15 \mathrm{mg}$ per day, ${ }^{53}$ which is an insufficient dose to induce remission in active moderate-to-severe IBD. Higher doses increase the risk of infection and premature delivery. ${ }^{54}$ Also, orofacial malformations are described in infants born to mothers exposed to corticosteroids in the first trimester. ${ }^{55}$ Indirectly, the risk of maternal complications such as hypertension, diabetes, and preeclampsia are also increased, ${ }^{56,57}$ which can be associated with unfavorable pregnancy outcomes. Based on these studies, it seems daring to say that corticosteroids are safer than infliximab or adalimumab during pregnancy. In fact, it seems to be the other way around.

It is well established that anti-TNFa agents themselves do not increase the risk of adverse pregnancy outcomes. ${ }^{16,58-60}$ Narula et a/ ${ }^{61}$ published the first meta-analysis 
reporting on the safety of infliximab, adalimumab and certolizumab treatment during pregnancy. Later, Shihab et a/62 issued a second meta-analyses that, again, found no increased risk of adverse pregnancy outcomes for patients on these anti-TNFa agents compared with matched controls. Optimizing disease control through anti-TNFa therapy during pregnancy is in the best interest of both mother and baby. Indeed, up-to-date practice guidelines recommend ongoing therapy to maintain disease remission. ${ }^{7,8}$

Maternal-fetal transport of $\operatorname{lgG}$ starts at the beginning of the second trimester, and is maximal during the third trimester, around gestational week 37 to $41 .{ }^{45}$ Studies addressing drug levels in the cord serum and blood of the newborn at the time of birth found that concentrations of infliximab and adalimumab were higher in infants than in the mothers - 160\% and $153 \%$ of maternal concentrations respectively. Furthermore, the drugs could be detected for as long as 6 months after birth. ${ }^{63}$ Julsgaard et a/64 further investigated infliximab and adalimumab washout timings and showed that the mean time for drug disappearance in infants was 4 months for adalimumab and 7.3 months for infliximab, and that no drug could be detected in children after 12 months of age.

There is no known safe level of infliximab or adalimum$a b$ in a newborn child. The worry is that exposure to these drugs may disrupt the babies' immune system maturation. Also, the high infant drug levels raise concerns regarding infant infection susceptibility. This speculative risk has led to recommendations to stop treatment to limit the newborn's exposure to anti-TNF $\alpha$ and avoid live virus vaccines for the first 6 - 9 months in children who were exposed to anti-TNFa treatment during pregnancy. ${ }^{7,8}$ To limit the fetus exposure to anti-TNFa treatment, the therapy can be stopped around gestational week 24 - 26 or as early as possible in the third trimester ${ }^{7,8}$ as infant drug levels negatively correlate with the timing of the last dose during pregnancy. ${ }^{64}$ However, Mahadevan et $a^{63}$ published data suggesting that interrupting anti-TNF $\alpha$ therapies during the third trimester, namely infliximab and adalimumab, does not completely prevent placental drug transfer and high infant drug levels at birth. The recommendation to stop treatment with anti-TNFa agents only applies to very specific cases, as the benefit of maintaining remission by treatment continuation exceeds the risks of fetal exposure. However, even for the specific cases, disease flares during pregnancy and early post-partum after antiTNF $\alpha$ discontinuation have been reported..$^{60,65}$ Furthermore, the consequences of treatment interruption may lead to lack of response later. ${ }^{66}$

For newborns exposed to anti-TNFa agents, the theoretical infection risk and the recommended vaccination policy has been extensively studied so far. In 2010, a healthy newborn from a mother who received infliximab throughout the pregnancy died unexpectedly after receiving the bacillus Calmette-Guérin (BCG) vaccine at 3 months of age. ${ }^{67}$ Subsequently, minor reports of skin infections and neutropenia in neonates that had been exposed to infliximab followed. ${ }^{68}$ No cases like these were ever reported again. Currently, there is no data that meets the theoretical risk for neona- tal derangement of normal immunological function. In fact, follow-up of a series of infants born to mothers exposed to infliximab and adalimumab ensured healthy infants and demonstrated normal response to haemophilus influenzae and tetanus vaccines, along with regular levels of $\lg A$ and $\operatorname{lgG} .{ }^{11,69-71}$ This data is consistent with the results from the PIANO registry. In this multicenter prospective study, the authors found that infant infections during the first year of life were not related to anti-TNFa exposure. ${ }^{72}$ Preliminary data published earlier, reported an increased risk of infection for newborns exposed to a combination of thiopurines and anti-TNFa, but not for anti-TNF $\alpha$ alone. ${ }^{73}$ Finally, two meta-analysis found that there is no data that demonstrates a risk of increased infection or neonate immune system disorder due to anti-TNFa exposure. ${ }^{61,62}$

Current guidelines recommend avoiding live vaccines, such as BCG and rotavirus, during the first 6 - 9 months for infants exposed to anti-TNFa treatment in utero. Other vaccination strategies follow the recommendations from national guidelines, as the infants can adequately respond to non-live vaccines. ${ }^{11}$ However, according to the author's professional experience, live vaccines may be inadvertently administered to infants before they reach 9 months of age. To avoid this, it is the author's opinion that parents should be handed a medical leaflet informing that live vaccines should be postponed in newborns exposed to anti-TNFa during pregnancy. This would easily make parents, physicians, and public health authorities aware of this recommendation.

Novel findings have demonstrated that anti-TNFa pharmacokinetics may be altered during pregnancy, and current guidelines do not address how to handle this. ${ }^{64,74,75}$ Julsgaard et a/ ${ }^{64}$ found that infliximab half-life was longer than adalimumab in exposed infants. In addition, Seow et $a \Gamma^{44}$ reported that maternal levels of infliximab increased during pregnancy even when keeping the non-pregnant weight adjustment, while adalimumab levels remained stable. In line with this, Seow et $a \Gamma^{4}$ showed that there is no need to adjust anti-TNFa dosages in response to pregnancy weight gain. Additionally, it is suggested that targeting the lower end of the therapeutic level range by therapeutic drug monitoring during pregnancy could possibly control high therapeutic infliximab levels and limit placental drug transfer. Recently, Kanis et $a l^{75}$ stated that adalimumab may be continued for a longer period during pregnancy, because transfer to the placenta is certainly lower than for infliximab.

In summary, there is still no evidence of a definitive advantage of one agent over the other, and it is too early to provide recommendations on the choice of anti-TNFa agent based on these reports alone.

Future studies should determine ways to ensure therapeutic levels for the mother and limited exposure for the fetus. Prospective data from the Pregnancy IBD and Neonatal Outcomes study (available in abstract form) on all medications used for IBD is also awaited. In the meantime, meta-analyses and reviews may provide reassurance to expectant parents and may guide clinician decisions. 


\section{CONCLUSION}

Anti-TNF $\alpha$ agents are efficient treatments for patients with moderate-to-severe IBD requiring lifelong maintenance therapy to avoid flares and a disabling disease course. Concerning pregnancy in IBD patients treated with anti-TNFa agents, it is widely accepted that disease activity is the best predictor of pregnancy outcomes, and there should be little disagreement as to the need to maintain therapy aiming to control the disease during gestation. Anti-TNFa agents cross the placenta and are found in high levels in the newborn at birth. This can be distressing for parents and medical doctors. Therefore, physicians handling these patients should be aware of the evidence regarding the safety of anti-TNF $\alpha$ agents during pregnancy for both mothers and fetus. In this review, we have made a critical revision of the most relevant data focusing on anti-TNFa therapy during pregnancy in IBD and demystified the risk of adverse pregnancy outcomes, teratogenicity, neonatal infections susceptibility, and newborn immune system disruption.

\section{ACKNOWLEDGEMENTS}

The authors would like to thank Scientific ToolBox Consulting, Lisbon, Portugal for providing editorial support.

\section{PROTECTION OF HUMANS AND ANIMALS}

The authors declare that the procedures were followed according to the regulations established by the Clinical Research and Ethics Committee and to the Helsinki Declaration of the World Medical Association.

\section{DATA CONFIDENTIALITY}

The authors declare having followed the protocols in use at their working center regarding patients' data publication.

\section{CONFLICTS OF INTEREST}

All authors report no conflict of interest.

\section{FUNDING SOURCES}

The authors received no financial support for the research, authorship or publication of this article

\section{REFERENCES}

1. Loftus EV Jr. Clinical epidemiology of inflammatory bowel disease: incidence, prevalence, and environmental influences. Gastroenterology. 2004;126:1504-7.

2. De Lima-Karagiannis A, Zelinkova- Detkova Z, van der Woude CJ. The effects of active IBD during pregnancy in the era of novel IBD therapies. Am J Gastroenterol. 2016;111:1-8.

3. Kammerlander H, Nielsen J, Kjeldsen J, Knudsen T, Friedman S, Nørgård B. The effect of disease activity on birth outcomes in a nationwide cohort of women with moderate to severe inflammatory bowel disease. Inflamm Bowel Dis. 2017;23:1011-8.

4. Moser MA, Okun NB, Mayes DC, Bailey RJ. Crohn's disease, pregnancy, and birth weight. Am J Gastroenterol. 2000;95:1021-6.

5. O'Toole A, Nwanne O, Tomlinson T. Inflammatory bowel disease increases risk of adverse pregnancy outcomes: a meta-analysis. Dig Dis Sci. 2015;60:2750-61.

6. Vermeire S, Carbonnel F, Coulie PG, Geenen V, Hazes JM, Masson $\mathrm{PL}$, et al. Management of inflammatory bowel disease in pregnancy. J Crohns Colitis. 2012;6:811-23.

7. Van der Woude CJ, Ardizzonne S, Bengtson MB, Fiorino G, Frase G, Katsanos K, et al. The second European-based consensus on reproduction and pregnancy in inflammatory bowel disease. J Crohns Colitis. 2015;107-24.

8. Nguyen GC, Seow CH, Maxwell C, Huang V, Leung $\mathrm{Y}$, Jones J, et al. The Toronto consensus statements for the management of inflammatory bowel disease in pregnancy. Gastroenterology. 2016;150:734-57.

9. Zelinkova Z, van der Ent C, Bruin KF, van Baalen O, Vermeulen HG, Smalbraak $\mathrm{HJ}$, et al. Effects of discontinuing anti-tumor necrosis factor therapy during pregnancy on the course of inflammatory bowel disease and neonatal exposure. Clin Gastroenterol Hepatol. 2013;11:318-21.

10. Nielsen $\mathrm{OH}$, Jess T. IBD: can TNF inhibitors be administered during the third trimester? Nat Rev Gastroenterol Hepatol. 2013;10:130-1.

11. Zelinkova Z, de Haar C, de Ridder L, Pierik MJ, Kuipers EJ, Peppelenbosch MP, et al. High intra-uterine exposure to infliximab following maternal anti-TNF treatment during pregnancy. Aliment Pharmacol Ther. 2011;33:1053-8.

12. Pitcher-Wilmott RW, Hindocha P, Wood CB. Placental transfer of IgG subclasses in human pregnancy. Clin Exp Immunol. 1980;41:303-8.

13. Friden BE, Makiya R, Nilsson BM, Holm S, Stigbrand TI. The human placental immunoglobulin $\mathrm{G}$ receptor and immunoglobulin $\mathrm{G}$ transport. Am J Obstet Gynecol. 1994;171:258-63.

14. Coe CL, Lubach GR, Izard KM. Progressive improvement in the transfer of maternal antibody across the order primates. Am J Primatol. $1994 ; 32: 51-5$.
15. Mahadevan U, Terdiman JP, Church J, Vasiliauskas E, Gitis A, Dubinsky MC. Infliximab levels in infants born to women with inflammatory bowel disease. Gastroenterology. 2007;132:A144.

16. Schnitzler F, Fidder H, Ferrante M, Ballet V, Noman M, Van Assche G, et al. Outcome of pregnancy in women with inflammatory bowel disease treated with anti-tumor necrosis factor therapy. Inflamm Bowel Dis. 2011;17:1846-54.

17. Ardizzone S, Bianchi Porro G. Biologic therapy for inflammatory bowel disease. Drugs. 2005;65:2253-86.

18. Peyrin-Biroulet L, Deltenre $P$, de Suray $N$, Branche J, Sandborn WJ, Colombel JF, et al. Efficacy and safety of tumor necrosis factor antagonists in Crohn's disease: meta-analysis of placebo-controlled trials. Clin Gastroenterol Hepatol. 2008;6:644-53.

19. Androulakis I, Zavos C, Christopoulos P, Mastorakos G, Gazouli M. Safety of anti-tumor necrosis factor therapy during pregnancy in patients with inflammatory bowel disease. World J Gastroenterol. 2015;21:13205-11.

20. FDA Simponi (Golimumab) - Prescribing information. 2017. [accessed 2018 Feb 5]. Available from: https://www.accessdata.fda.gov/ drugsatfda_docs/label/2015/125289s024lbl.pdf.

21. Martin PL, Oneda S, Treacy G. Effects of an anti-TNF-alpha monoclonal antibody, administered throughout pregnancy and lactation, on the development of the macaque immune system. Am J Reprod Immunol. 2007;58:138-49.

22. FDA Cimzia (certolizumab pegol) - Prescribing information. 2017 [accessed 2018 Feb 5]. pp. 1-40. Available from: https://www. accessdata.fda.gov/drugsatfda_docs/label/2017/125160s270lbl.pdf.

23. Stephens $P$, Nesbitt A, Foulkes R. Placental transfer of the anti-TNF antibody TN3 in rats: comparison of immunoglobulin G1 and pegylated Fab versions. Gut. 2006;55:A8

24. Mariette X, Förger F, Abraham B, Flynn AD, Moltó A, Flipo RM, et al. Lack of placental transfer of certolizumab pegol during pregnancy: results from CRIB, a prospective, postmarketing, pharmacokinetic study. Ann Rheum Dis. 2018;77:228-33.

25. Medicines.org.uk/emc. Merck Sharp \& Dohme Limited. Summary of product characteristics: remicade $100 \mathrm{mg}$ powder for concentrate for solution for infusion. [accessed 2018 Oct 14]. Available from http://emc. medicines.org.uk/medicine/3236/.

26. Lapadula G, Marchesoni A, Armuzzi A, Blandizzi C, Caporali R, Chimenti $\mathrm{S}$, et al. Adalimumab in the treatment of immune-mediated diseases. Int J Immunopathol Pharmacol. 2014;27:33-48.

27. Magro F, Portela F. Management of inflammatory bowel disease with infliximab and other anti-tumor necrosis factor alpha therapies. Biodrugs. 
2010;24:3-14

28. Torres J, Boyapati RK, Kennedy NA, Louis E, Colombel JF, Satsangi J, et al. Systematic review of effects of withdrawal of immunomodulators or biologic agents from patients with inflammatory bowel disease. Gastroenterology. 2015;149:1716-30.

29. Lin HC, Chiu CC, Chen SF, Lou HY, Chiu WT, Chen YH. Ulcerative colitis and pregnancy outcomes in an Asian population. Am J Gastroenterol. 2010;105:387-94.

30. Mahadevan U, Sandborn WJ, Li DK, Hakimian S, Kane S, Corley DA Pregnancy outcomes in women with inflammatory bowel disease: a large community-based study from Northern California. Gastroenterology. 2007;133:1106-12.

31. Oron G, Yogev Y, Shcolnik S, Hod M, Fraser G, Wiznitzer A, et al. Inflammatory bowel disease: risk fac- tors for adverse pregnancy outcome and the impact of maternal weight gain. J Matern Fetal Neonatal Med. 2012;25:2256-60.

32. Stephansson $\mathrm{O}$, Larsson $\mathrm{H}$, Pedersen L, Kieler $\mathrm{H}$, Granath $\mathrm{F}$, Ludvigsson JF, et al. Crohn's disease is a risk factor for preterm birth. Clin Gastroenterol Hepatol. 2010;8:509-15.

33. Stephansson O, Larsson H, Pedersen L, Kieler H, Granath F, Ludvigsson $\mathrm{JF}$, et al. Congenital abnormalities and other birth outcomes in children born to women with ulcerative colitis in Denmark and Sweden. Inflamm Bowel Dis. 2011;17:795-801.

34. Nguyen GC, Boudreau H, Harris ML, Maxwell CV. Outcomes of obstetric hospitalizations among women with inflammatory bowel disease in the United States. Clin Gastroenterol Hepatol. 2009;7:329-34.

35. Raatikainen K, Mustonen J, Pajala MO, Heikkinen M, Heinonen S. The effects of pre- and post-pregnancy inflammatory bowel disease diagnosis on birth outcomes. Aliment Pharmacol Ther. 2011;33:333-9.

36. Bortoli A, Pedersen N, Duricova D, D'Inca R, Gionchetti P, Panelli MR, et al. Pregnancy outcome in inflammatory bowel disease: prospective European case-control ECCO-EpiCom study, 2003-2006. Aliment Pharmacol Ther. 2011;34:724-34.

37. Koren G, editor. Maternal-fetal toxicology. A clinician's guide. $3^{\text {rd }} \mathrm{ed}$. New York: McGraw Hill, Marcel Dekker Inc; 2008. p. 1.

38. Koren G, Pastuszak A, Ito S. Drugs in pregnancy. N Engl J Med. 1998;338:1128-37.

39. Huppertz B. The anatomy of the normal placenta. J.Clin Pathol. 2008;61:1296-302.

40. Palmeira P, Quinello C, Silveira-Lessa AL, Zago CA, Carneiro-Sampaio M. IgG placental transfer in healthy and pathological pregnancies. Clin Dev Immunol. 2012;2012:13.

41. Brambell FW. The passive immunity of the young mammal. Biol Rev. 1958;33:485-531.

42. Simister NE. Placental transport of immunoglobulin G. Vaccine. 2003;21:3365-9.

43. Hobbs JR, Davis JA. Serum gamma-G-globulin levels and gestational age in premature babies. Lancet. 1967;1:757-9.

44. Van den Berg JP, Westerbeek EA, van der Klis FR, Berbers GA, van Elburg RM. Transplacental transport of IgG antibodies to preterm infants: a review of the literature. Early Hum Dev. 2011;87:67-72.

45. Malek A, Sager R, Kuhn P, Nicolaides KH, Schneider $H$. Evolution of maternofetal transport of immuno-globulins during human pregnancy. Am J Repro Imunol. 1996;36:248-55.

46. Kohler PF, Farr RS. Elevation of cord over maternal IgG immunoglobulin: evidence for an active placental IgG transport. Nature. 1966;210:10701.

47. Landor M. Maternal-fetal transfer of immunoglobulins. Ann Allergy Asthma Immunol. 1995;74:279-83.

48. Kane SV, Acquah LA. Placental transport of immunoglobulins: a clinical review for gastroenterologists who prescribe therapeutic monoclonal antibodies to women during conception and pregnancy. Am J Gastroenterol. 2009;104:228-33.

49. Marshall-Clarke S, Reen D, Tasker L, Hassan J. Neonatal immunity: how well has it grown up? Immunol Today. 2000;21:35-41.

50. Griffioen AW, Franklin SW, Zegers BJ, Rijkers GT. Expression and functional characteristics of the complement receptor type 2 on adult and neonatal B lymphocytes. Clin Immunol Immunopathol. 1993;69:1-8.

51. Wild AE. Transport of immunoglobulins and other proteins from mother to young. In: Lysosomes in Biology and Pathology. Dingle JT, editor. $3^{\text {rd }}$ ed. Amsterdam: North-Holland; 1973. p. 169-215.

52. Koren G, Ornoy A. The role of the placenta in drug transport and fetal drug exposure. Expert Rev Clin Pharmacol. 2018;11:373-85.

53. Mahadevan U, Cucchiara S, Hyams JS, Steinwurz F, Nuti F, Travis SP, et al. The London Position Statement of the World Congress of Gastroenterology on Biological Therapy for IBD with the European
Crohn's and Colitis Organisation: pregnancy and paediatrics. Am J Gastroenterol. 2011;106:214-23.

54. Østensen M, Förger F. Management of RA medications in pregnant patients. Nat Rev Rheumatol. 2009;5:382-390.

55. Park-Wyllie L, Mazzotta P, Pastuszak A, Moretti ME, Beique L, Hunnisett $L$, et al. Birth defects after maternal exposure to corticosteroids: Prospective cohort study and meta-analysis of epidemiological studies. Teratology. 2000;62:385-92.

56. Martel MJ, Rey E, Beauchesne MF, Perreault S, Lefebvre G, Forget A, et al. Use of inhaled corticosteroids during pregnancy and risk of pregnancy induced hypertension: nested case-control study. BMJ. 2005;330:230

57. Pang S, Clark AT, Freeman LC, Dolan LM, Immken L, Mueller OT, et al. Maternal side effects of prenatal dexamethasone therapy for fetal congenital adrenal hyperplasia. J Clin Endocrinol Metab. 1992;75:24953.

58. Lichtenstein GR, Feagan BG, Mahadevan U, Salzberg BA, Langholff W, Morgan GJ, et al. Pregnancy outcomes reported during the 13year TREAT registry: a descriptive report. Am J Gastroenterol. 2018;113:1678-88.

59. Luu M, Benzenine E, Doret M, Michiels C, Barkun A, Degand T, et al. Continuous anti-TNFa use throughout pregnancy: possible complications for the mother but not for the fetus. A retrospective cohort on the French National Health Insurance Database (EVASION). Am J Gastroenterol. 2018;113:1669-77.

60. Nielsen OH, Loftus EV Jr, Jess T. Safety of TNF-alpha inhibitors during IBD pregnancy: a systematic review. BMC Med. 2013;11:174.

61. Narula N, Al-Dabbagh R, Dhillon A, Sands B, Marshall JK. Anti-TNF a therapies are safe during pregnancy in women with inflammatory bowe disease: a systematic review and meta-analysis. Inflamm Bowel Dis. 2014;20:1862-9.

62. Shihab Z, Yeomans N, Cruz P. Anti-tumor necrosis factor $\alpha$ therapies and inflammatory bowel disease pregnancy outcomes: a meta-analysis. J Crohns Colitis. 2016;10:979-88

63. Mahadevan U, Wolf DC, Dubinsky M, Cortot A, Lee SD, Siegel CA, et al. Placental transfer of anti-tumor necrosis factor agents in pregnant patients with inflammatory bowel disease. Clin Gastroenterol Hepatol. 2013;11:286-92.

64. Julsgaard M, Christensen LA, Gibson PR, Gearry RB, Fallingborg $\mathrm{J}$, Hvas CL, et al. Concentrations of adalimumab and infliximab in mothers and newborns, and effects on infection. Gastroenterology. 2016;151:110-9.

65. Seirafi M, de Vroey B, Amiot A, Seksik P, Roblin X, Allez M, et al. Factors associated with pregnancy outcome in anti-TNF treated women with inflammatory bowel disease. Aliment Pharmacol Ther. 2014;40:363-73.

66. Rutgeerts P, Feagan BG, Lichtenstein GR, Mayer LF, Schreiber S, Colombel JF, et al. Comparison of scheduled and episodic treatment strategies of infliximab in crohn's disease. Gastroenterology. 2004;126:402-13.

67. Cheent K, Nolan J, Shariq S, Kiho L, Pal A, Arnold J, et al. Crohns colitis. Case report: fatal case of disseminated BCG infection in an infant born to a mother taking infliximab for Crohn's disease. J Crohns Colitis. 2010;4:603-5.

68. Ling J, Koren G. Challenges in vaccinating infants born to mothers taking immunoglobulin biologicals during pregnancy. Expert Rev Vaccines. 2016;15:239-56.

69. Martin PL, Oneda S, Treacy G. Effects of an anti-TNFa monoclonal antibody, administered throughout pregnancy and lactation, on the development of the macaque immune system. Am J Reprod Immunol. 2007;58:138-49.

70. Sheibani S, Cohen R, Kane S, Dubinsky M, Church JA, Mahadevan $U$. The effect of maternal peripartum anti-TNFa use on infant immune response. Dig Dis Sci. 2016;61:1622-7.

71. Mishkin DS, Van Deinse W, Becker JM, Farraye FA. Successful use of adalimumab (Humira) for Crohn's disease in pregnancy. Inflamm Bowel Dis. 2006;12:827-8.

72. Mahadevan U, Martin CF, Dubinsky M, Kane SV, Sands BE, Sandborn W. Exposure to anti-TNFa therapy in the third trimester of pregnancy is not associated with increased adverse outcomes: results from the PIANO registry. Gastroenterology. 2014;146:S170.

73. Mahadevan U, Martin CF, Sandler RS, Kane SV, Dubinsky M, Lewis JD, et al. PIANO: a 1000 patient prospective registry of pregnancy outcomes in women with IBD exposed to immunomodulators and biologic therapy. Gastroenterology. 2012;142:S149.

74. Seow CH, Leung Y, Vande Casteele N, Ehteshami Afshar E, Tanyingoh $D$, Bindra $G$ et al. The effects of pregnancy on the pharmacokinetics 
of infliximab and adalimumab in inflammatory bowel disease. Aliment Pharmacol Ther. 2017;45:1329-38.

75. Kanis SL, de Lima-Karagiannis A, van der Ent C, Rizopoulos D, van der
Woude CJ. Anti-TNF levels in cord blood at birth are associated with anti-TNF type. J Crohns Colitis. 2018;12:939-47. 